\title{
Forgery and Appreciation of Old Choir Books in Nineteenth-Century Europe
}

\begin{abstract}
The nineteenth century saw a revival in the illumination of manuscripts in Europe, involving amateurs as well as professional painters. Today, however, a significant part of the resulting written artefacts are declared to be forgeries without strong evidence, which often hinders further investigation into their context of origin and use. The current study aims to precisely investigate these contexts in Italy. Manuscripts, that contain musical notation as well as illuminations will be focused on as case studies. Overall, this article illustrates the broad 19th-century interest in illuminated manuscripts and discusses contemporary ideas of the terms 'original' and 'copy' in relation to newly produced written artefacts.
\end{abstract}

\section{Introduction}

At some point during his term as President of the United States of America, Theodore Roosevelt (1858-1919) met the publisher, book designer, and book historian William Dana Orcutt (1870-1953) and showed him an illuminated manuscript that he had received as a gift from King Menelik of Abyssinia (18441913). Although 'someone' had told the president that this was a manuscript from the twelfth or thirteenth century, he asked Orcutt: 'Is this an original manuscript?' Orcutt, realising that it was, in fact, a 'modern copy', steered the conversation to different topics so as not to have to reveal his opinion on the manuscript. ${ }^{1}$ It is not clear when exactly Roosevelt received this gift; however, a letter from Menelik to Roosevelt attests to other items exchanged by the two men in 1903. No additional manuscripts are listed in this document that makes reference to a photograph, a typewriter, guns, lions, and elephant tusks. ${ }^{2}$

1 This anecdote is reported in Orcutt 1926, 104-105.

2 See 'Translation of letter from Emperor Menelik II to Theodore Roosevelt', Theodore Roosevelt Papers, Library of Congress Manuscript Division, available on the Theodore Roosevelt Digital Library (Dickinson State University): <https://theodorerooseveltcenter.org/Research/DigitalLibrary/Record?libID=043319> (accessed on 17 March 2021). 
The situation just described reveals some of the difficulties encountered when using the terms 'original' and 'copy' in relation to manuscripts: while the illuminated manuscript was identified as an original by an unnamed individual, this was obviously not completely convincing to the president. The expert Orcutt, who had studied many illuminated manuscripts, judged the manuscript to be modern based on the parchment and the colours employed. ${ }^{3}$ If Orcutt was right, should the manuscript have been considered a forgery?

The terms 'original,' 'copy,' and 'forgery' are still controversial ${ }^{4}$ and are not used consistently when applied to the nineteenth- or twentieth-century illuminated manuscripts: The term 'original' often refers to an old manuscript only, and a nineteenth-century copy or imitation of a medieval manuscript is often described as a forgery. When such written artefacts are classified as forgeries today, the descriptions often resemble detective stories in which the guilty one - the forger - is pinpointed; there is often considerable drama involved. ${ }^{5}$ While this may be an exciting read for some, analysis of the respective manuscripts as written artefacts is usually neglected. This applies to a specific group of European sources in particular, on which I will focus in the following.

Fig. 1 shows fol. $69^{\mathrm{r}}$ from the manuscript Toronto, Thomas Fisher Rare Book Library, MSS 09700 ('Fisher Antiphonary'), a liturgical book that was most likely made in Northern Italy in the fifteenth or early sixteenth century and that belonged to the Franciscan order. There are some later additions suggesting that the manuscript was in liturgical use until the eighteenth century. ${ }^{6}$ In the second half of the nineteenth century, 22 folios received new historiated initials, bas-de-page miniatures, and border decorations. It is probable that the manuscript later made its way to the Libreria Franceschini in Florence; Wilfrid Voynich (1864-1930) purchased the bookshop and its inventory in 1908. In September of the following year, Voynich sold the antiphonary to the Royal Ontario Museum in Toronto, from where it was transferred to the Thomas Fisher Rare Book Library in $1964 .{ }^{\circ}$

The Royal Ontario Museum's 1909 card catalogue entry draws attention to a peculiar feature of the folio in Fig. 1, namely that the 'miniature scenes in the

3 Orcutt 1926, 104-105.

4 See Michel and Friedrich 2020.

5 Römer 2006, 347.

6 Piazza 2019.

7 This has been proven through material analysis - using the CSMC's mobile lab - conducted by Sebastian Bosch and Andreas Janke on-site at the Thomas Fisher Rare Book Library, Toronto. See Bosch and Janke 2021.

8 See Bosch and Janke 2021. 
capital letter' contain a 'Praying Madonna (from Fra Filippo Lippi: Madonna in Adoration, c. 1435)'. ${ }^{9}$ The cataloguer drew attention to the fact that a section of the Florentine painting, now in the Uffizi Gallery, served as the model for this nineteenth-century illumination. The border decoration and the initial ' $P$ ' were copied from different illuminated manuscripts, for the most part choir books, and the initial ' $\mathrm{P}$ ' does not relate to any text on this folio. Finally, it is important to point out that the historiated initial obscures text and musical notation in the antiphonary.

In addition to the Fisher Antiphonary, which contains many more such examples (e.g. Fig. 3), there is a growing number of single leaves, stemming from Late Medieval or Early Renaissance choir books, which have received additional illuminations that do not align with the liturgical content. These are listed as nos 1-4 in the Appendix, which includes additional leaves illuminated in the nineteenth or early twentieth century and which I will refer to in the following by the numbers I have assigned. Based on style and technique, no. 5, for example, seems to originate from the workshop in which the Fisher Antiphonary received its new decoration and it contains a full-page miniature, likewise copied from Lippi's painting, and additional decorative elements reproduced from different choir books. In this case, however, a piece of parchment was reused, one that had served as a credit contract in eighteenth-century Florence.

The Fisher Antiphonary and leaves nos 2 and 3 have been described as forgeries. ${ }^{10}$ In the following, however, I would like to try to interpret such written artefacts principally in their role as copies or imitations of 'original' late Medieval or Renaissance choir books. First, I will use the example of the well-known 'Spanish Forger'11 to highlight problems with common criteria for labelling illuminated manuscripts as forgeries. Secondly, I will demonstrate the broad interest in and access to Late Medieval and Renaissance illuminated choir books in nineteenth-century Italy. This is fundamental for, thirdly, gaining greater insights into the popular nineteenth-century practices of illuminating manuscripts and ideas on the relationship between original and copy. Finally, I will emphasize how a genuine interest in the visual organisation and materiality of choir books emerged at that time, which continues to this day.

9 I thank Kathleen Ruffo for granting me access to the card catalogue at the Royal Ontario Museum.

10 See Michael Scott Cuthbert's online comment, <https://gregorian-chant.ning.com/group/ arsnovaetarssubtilior/forum/topics/copy-of-squarcialupi-codex-auction-2014> (unless otherwise stated, all sites were accessed on 1 Sept. 2020), and W. M. Voelkle in Holy Hoaxes 2019, 41 and 44. 11 On the 'Spanish Forger' see Voelkle 1978 and 2007, The Spanish Forger 1987, and Holy Hoaxes 2019. 


\section{How to not unmask a forger}

When it comes to what are identified as forged illuminated manuscripts in nineteenth- or early twentieth-century Europe, it is often assumed that they were created in forgery workshops. Such workshops, however, cannot be described in detail, let alone documented. Therefore, all investigative approaches are inevitably based almost exclusively on the objects identified as forgeries.

A frequently used example is that of the so-called 'Spanish Forger', to whom an extensive oeuvre of forgeries is ascribed, including 284 illuminated parchment leaves, 11 codices, and 117 panels, most of them have been considered to stem from the Middle Ages or the Renaissance, at some point. ${ }^{12} \mathrm{He}$ is often described as 'one of the most skilful, successful, and prolific forgers of all time', ${ }^{13}$ 'master of deception', ${ }^{14}$ and 'master of manuscript chicanery' ${ }^{15}$ So far, only a few assumptions have been made about his identity: he might have been active in France, first as a chromolithographer at the end of the nineteenth century and then, from about 1900, as a forger. Based on material analysis, some of his works could be proven to be not older than 1814, which does not allow for a medieval or Renaissance origin of the artefacts. ${ }^{16}$ Attribution to the Spanish Forger is usually determined by specific and consistent features in the illuminations including, among others, '[...] sugary faces, daring décolletage, page costumes, theatrical postures and hand gestures, stock figures, tapestry-like foliage, swirling waters, and stage set architecture'. ${ }^{17}$

A large part of the literature on forgery focuses on the forger's techniques, usually described exhaustively. ${ }^{18}$ Of particular interest are details by which a forgery can be exposed. The most common characteristics attributed to the Spanish Forger's manuscripts, for example, include: ${ }^{19}$

- the copying of miniatures and border decorations from contemporary reproductions of medieval manuscripts in printed volumes;

\footnotetext{
12 Holy Hoaxes 2019, 12.

13 Voelkle 1978, 9; The Spanish Forger 1987, 13; Hindman and Rowe 2001, 157; Voelkle 2007, 207; Holy Hoaxes 2019, 12.

14 The Spanish Forger 1987.

15 Voelkle 2007, 207.

16 Holy Hoaxes 2019, 12.

17 Voelkle 2007, 207.

18 Römer 2006, 348-349.

19 See for example Voelkle 2007, 207-210, 212-213, 216-217, 219, 224; The Spanish Forger 1987, 32; Hindman and Rowe 2001, 158-159; Holy Hoaxes 2019, 3-4, 23.
} 
- development of his own personal style;

- use of old vellum, usually from late medieval choir books;

- erasure of musical notation and text before a new miniature was painted;

- if original chant from the choir book is still visible it typically bears no relationship to the new illumination; and

- when gold paint or leaf are used they are treated to create an 'antiqued' look.

The term 'forgery' is typically used without a clear definition, since a general understanding of the term is assumed. One of the unquestionable characteristics of a forgery is that it was created with the intent to deceive someone for profit. The word 'fake' is mostly used as a synonym for 'forgery', but there are also other uses of 'fake', for example synonymous to 'hoax', meaning a forgery with the intention of being exposed as such after a certain period of time. ${ }^{20}$

In the recent exhibition catalogue Holy Hoaxes (2019) some manuscripts are identified as forgeries, although they were obviously not created with the intent to deceive ${ }^{21}$ and should therefore instead be described as copies, pastiches, or imitations. ${ }^{22}$ The classification of a written artefact as forgery is indeed no trivial act, as can be seen from semiotician Umberto Eco's discussion of what constitutes a forgery:

[T] he necessary conditions for a forgery are that, given the actual or supposed existence of an object Oa, made by A (be it a human author or whatever) under specific historical circumstances $\mathrm{t}$, there is a different object $\mathrm{Ob}$, made by $\mathrm{B}$ (be it a human author or whatever) under circumstances $\mathrm{t}$, which under a certain description displays strong similarities to $\mathrm{Oa}$ (or with a traditional image of $\mathrm{Oa}$ ). The sufficient condition for a forgery is that it be claimed by some Claimant that $\mathrm{Ob}$ is indiscernibly identical with $\mathrm{Oa}$.

The current notion of forgery generally implies a specific intention on the part of the forger, that is, it presupposes dolus malus. However, the question whether $\mathrm{B}$, the author of $\mathrm{Ob}$, was guilty of dolus malus is irrelevant (even when $\mathrm{B}$ is a human author). B knows that $\mathrm{Ob}$ is not identical with $\mathrm{Oa}$, and he or she may have produced it with no intention to deceive, either for practice or as a joke, or even by chance. Rather, we are concerned with any Claimant who claims that $\mathrm{Oa}$ is identical to $\mathrm{Ob}$ or can be substituted for it - though of course the Claimant may coincide with B.

However, not even Claimant's dolus malus is indispensable, since he or she may honestly believe in the identity he or she asserts.

20 See Doll 2012, 21-25 and Keazor 2018, 12 and 29.

21 For example, Holy Hoaxes 2019, item no. 64, p. 73 and the comment on p. 3.

22 On these terms see, for example Keazor 2018, 12. 
Thus a forgery is always such only for an external observer - the Judge - who, knowing that $\mathrm{Oa}$ and $\mathrm{Ob}$ are two different objects, understand that the Claimant, whether viciously or in good faith, has made a false identification. ${ }^{23}$

With regard to the Spanish Forger (B), difficulties arise immediately in defining the manuscripts on which he worked $(\mathrm{Ob})$ as very similar to known printed originals $(\mathrm{Oa})$, on the one hand because of the different materials used and, on the other hand, because of recognisable alterations he made. What is missing is the 'Claimant' claiming that $\mathrm{Ob}$ is identical with Oa. Oa can also be an object that no longer exists, in which case it would be a forgery ex nihilo. ${ }^{24}$ It is important to emphasise that none of the criteria listed above allow the works of the Spanish Forger to be understood as 'false identifications'.

At this point, even scientific material analysis is only of limited help. ${ }^{25}$ The hope of many scholars in the humanities - who are accustomed to weighing plausibilities - that they might use scientific methods to arrive at an unambiguous determination of whether a forgery is present must inevitably fail in most cases. Certainly, the composition of the colours in illuminated manuscripts can be determined. However, if modern pigments are identified, the analytical technique does not rise to the level of proof of intent to deceive.

Future research should focus more on the 'Claimant' in cases of suspected counterfeiting, who can either be the originator of a written artefact or the seller of a manuscript, for example. The challenges in the identification of forgeries I addressed here for a specific region and time frame are not limited to Europe or the nineteenth or early twentieth century, but remain relevant today. ${ }^{26}$

\section{Tourist guides to illuminated choir books}

Looking back in 1926, Orcutt states that no 'true lover of art' would travel to Europe without preparation and explicitly refers to illuminated manuscripts, adding that one should 'make an equal effort to prepare himself to understand and enjoy those rich treasures in the art of illumination which are now so easily

23 Eco 1990, 180-181. On Eco see also Doll 2012, 34-39.

24 Eco 1990, 186.

25 As, for example, described in Voelkle 2007, 219-220. On the limits of material analysis, see Rabin and Hahn 2020.

26 See, for example, Gallop 2017. 
accessible'. ${ }^{27}$ In the nineteenth century, illuminations in Late Medieval or Renaissance manuscripts were considered works of arts and were, along with other important artworks, among the objects travellers were most eager to see. ${ }^{28}$ Although scholars often assume these travellers had no access to original manuscripts and knew them only from chromolithographic reproductions, for example, ${ }^{29}$ there were in fact specific institutions with large numbers of choir books on display. Florence and Siena are particularly good examples of this. Even for the 'unlettered visitor' ${ }^{30}$ there were countless instructions in travel guides which revealed where the most important illuminated manuscripts many of them choir books - were located. The three most relevant sites are briefly highlighted here: Florence's Laurentian Library and the Museum of San Marco and, in Siena, the Cathedral's Piccolomini Library.

The Laurentian Library was usually open from 9 am to 3 pm. From Murray's Handbook of Florence and its Environs the traveller learns that:

The assistant will expect a small gratuity. The chief librarian is generally in attendance, and those who wish to consult or use the manuscripts will experience, as in the other public establishments of this city, all the facilities they can desire. ${ }^{31}$

The most valuable manuscripts of the library are listed as 'sights' ${ }^{32}$ Their popularity was such that in 1872 there were more tourists interested in 'the beauty of the place and the rarities that are preserved there' than scholars. ${ }^{33}$ The place itself was certainly part of the experience, with its connections to the Medici family, Michelangelo Buonarotti, and Giorgio Vasari, among others. ${ }^{34}$ In her 'new artistic and practical hand-book for English and American tourists', Saunterings in Florence (1896), Elvira Grifi reports that in the Laurentian Library 'another room has been opened for the choral books especially those of Sta. Maria del Fiore and Sta. Maria Angioli'. She remarks as well that 'the Librarian is usually willing to show any desired Mss. ${ }^{35}$

The Museum of San Marco has been a similarly attractive destination for tourists since 1869; there, in addition to the illuminated choir books exhibited in

27 Orcutt 1926, 152.

28 This interest began well before the nineteenth century. See Chapron 2004.

29 Wieck 1996, 243; Hindman and Rowe 2001, 160; Voelkle 2007, 216.

30 Murray 1867, 37.

31 Murray 1867, 38.

32 Murray 1867, 37.

33 Anziani 1872, 36.

34 See Horner's Walks in Florence 1884, vol. I, 134-140.

35 Grifi 1896, 128. 
vitrines (organised according to their provenance) ${ }^{36}$ travellers could also admire frescoes and the former monastery. In 1872 the director, Ferdinando Rondoni, published an extensive inventory including, among other items, all miniatures found in the library's 82 choir books and identifying the respective miniaturists when known. ${ }^{37}$ Choir books could be examined in detail by the visitors by making a request..$^{38}$ The vitrines are explicitly referred to in travel guides, ${ }^{39}$ and in Horner's Walks in Florence it is even suggested that visitors purchase Rondoni's guide at the museum's entrance. ${ }^{40}$

Before Rondoni's work, Gaetano Milanesi wrote a history of Italian miniature painting in 1850, which, in addition to biographies of individual miniaturists, lists about 40 choir books in different archives and describes their miniatures in detail. ${ }^{41}$ His interests were scholarly in nature and he was concerned about the preservation of the manuscripts. He stated that the illuminated choir books should be stored as carefully as possible and - where still in use replaced with copies. This had apparently already been done at Siena Cathedral, where the old choir books were now exhibited in the Piccolomini Library. Milanesi noted, however, that 'those codices are not completely saved from the slow but continuous offense that they receive from the everyday opening and unfolding to the curiosity of visitors' ${ }^{42}$

\section{Designing manuscripts}

Nineteenth-century interest in illuminated manuscripts was quite diverse and included collection and research, among others. Often initials and miniatures were cut from the manuscripts and the cuttings then often rearranged in collages. In addition to these practices, manuscripts or parts of manuscripts were more and more frequently copied..$^{43}$ In London in particular, institutions such as

36 For a recent study of the twenty-two choir books that originate from different Franciscan houses, see Labriola 2020.

37 Rondoni 1872.

38 Rondoni 1872, VI.

39 E.g. Grifi 1896, 158.

40 Horner 1884, vol. I, 422 (footnote).

41 Milanesi 1850. On Milanesi see Labriola 2016.

42 'Ma questo non basta, imperciòcche quei Codici non sono del tutto salvati dalla lenta ma continua offesa che ricevano dal quotidiano aprirli e svolgerli alla curiosità de'visitatori della Sala Piccolominea' (Milanesi 1850, 192).

43 See Hindman and Rowe 2001. 
the South Kensington Museum (later the Victoria and Albert Museum) and the Arundel Society commissioned professional facsimilists to produce high-quality copies especially of Late Medieval and Renaissance frescoes and illuminated manuscripts. The facsimilists were active in the places I have highlighted above. Fig. 2 shows a parchment leaf commissioned by the Arundel Society that was copied from fol. $3^{\mathrm{r}}$ of the 'Gradual B' (MS 516) in San Marco. ${ }^{44}$ Arranged as a collage, only the initial ' $R$ ' and some border decorations were copied and rearranged ${ }^{45}$ In addition, a hand-painted facsimile of the complete folio, including a correct reproduction of the chants, was created by Jacopo Olivotto (Appendix, no. 6). It seems, therefore, that certain manuscripts had become especially attractive as templates and the direct access to original choir books was not only of importance for tourists and scholars, but also for all those who wanted to use the manuscripts directly as templates from which to copy. ${ }^{46}$

The monastery of San Marco was already a destination for illuminators and copyists even before it opened as a museum. The English writer and art historian Elizabeth Eastlake (1809-1893), for example, who studied choir books in Brussels and Bologna in $1860,{ }^{47}$ was at San Marco on 30 September 1863 to copy from choir books. ${ }^{48}$

Such interests were fuelled by publication of numerous - principally British - manuals offering step-by-step instructions on how to illuminate manuscripts. A major motivation for this was commercial interest on the part of paint manufacturers, who published most of the manuals. ${ }^{49}$ Some of these included reproductions of initials and miniatures, particularly those from the fourteenth and fifteenth centuries, along with instructions for tracing which enabled amateur painters to quickly achieve good results without much practice. Many of the manuals also promulgated a revival of manuscript illumination as the higher goal for ambitious amateurs and professional illuminators. In Italy, the first such known manual of this type was published in 1905 by Vittorio Vulten. ${ }^{50}$

44 The manuscript is described in Rondoni's Guida (Rondoni 1872, 33-34).

45 The Arundel Society also commissioned copies from the Siena choir books in the Piccolomini Library, many of which were made by Ernesto Sprega (Ledger 1978, 128 and 292).

46 At the time the monastery of San Marco received special mention in travel guides for its illuminated manuscripts. See Murray 1867, 40.

47 Rigby 1895, vol. 2, 148 and 156.

48 Ribgy 1895, vol. 2, 171-172.

49 Watson 2007, esp. 93.

50 Vulten 1905. 
However, template books with initials, miniatures, and border decorations from different manuscripts had been published earlier as chromolithographs. ${ }^{51}$

The appeal certain manuscripts held for painters is documented at the Laurentian Library; for example, a Breviarium Romanum (Florence, Biblioteca Medicea Laurenziana, Pluteo 17,1), illuminated by Boccardino the Elder (1460-1529), attracted a particularly large number of painters towards the end of the nineteenth century. The library's 'list of readers ${ }^{52}$ of this manuscript contains the name of the aforementioned Jacopo Olivotto several times, as well as many others whose professions were clearly given as painters. The director of the Laurentian Library was not unaware of the attention given his collection of illuminated manuscripts and so in 1890 he published an article connecting the most famous illuminator from this group - Nestore Leoni (1862-1947) ${ }^{53}$ - with the miniaturist Boccardino the Elder, after he explained that 'today it is fashionable to have diplomas and parchments executed in imitation of ancient miniatures [...] ${ }^{54}$

Returning to the examples from the Fisher Antiphonary (Figs 1 and 3), it becomes clear, based on these parameters, that they were not intended to serve as facsimiles - they are, rather, pastiches. In Fig. 3 the same initial 'P' seen in Fig. 1 recurs, though the border decoration is based on different models. The painted scene within the initial also has a different source, it is based on Benozzo Gozzoli's frescoes in the chapel of the Palazzo Medici-Riccardi (see also Fig. 4). This is not unprecedented, as frescoes served as models for the decoration of other manuscripts (see Appendix, no. 7).

Gozzoli's frescoes had long been one of the main tourist attractions in Florence ${ }^{55}$ and the group of angels that served as the model for Fig. 3 was particularly renowned: 'The most beautiful group is of kneeling angels with their hands

51 Melani 1896. The intended audience included not only illuminators, but also calligraphers, sign painters, embroiderers, engravers, and type designers. Tables XVII-XVIII and XI contain initials copied from choir books located in Venice and Pistoia.

52 Florence, Biblioteca Medicea Laurenziana, Elenco dei Lettori che hanno studiato il seguente Manoscritto: Plut.17,1, from 6 Nov. 1889 to 23 May 1998.

53 Nestore Leoni saw manuscript Plut. 17,1 in the Laurentian Library on 6 Nov. 1889. See Florence, Biblioteca Medicea Laurenziana, Elenco dei Lettori che hanno studiato il seguente Manoscritto: Plut. 17,1, no. 1. On Nestore Leoni in the context of an Italian revival of the manuscript illumination tradition see Ascoli 2007 and Guernelli 2011.

54 Biagi 1890, 269.

55 The frescoes are highlighted in almost every tourist guide to the city. See, for example, Grifi 1896, 145: 'The frescoes by Benozzo Gozzoli [...]. They constitute one of the most interesting works in Florence both for their merits as pictures as well for their excellent preservation'. 
joined, for when they arrive at the crib, where the Redeemer is, they worship and pray. ${ }^{56}$ Gozzoli's works also received considerable attention in England, where he was considered 'a "God" among Painters' in Pre-Raphaelite circles. ${ }^{57}$ The Arundel Society made many efforts to have the frescoes at the Palazzo Medici-Riccardi copied on-site and then reproduced as lithographs or chromolithographs. ${ }^{58}$ This undertaking was especially complicated due to unfavourable lighting conditions in the chapel. ${ }^{59}$ But, following the advent of photography, copyists were not limited to making reproductions on-site. A wide range of photographic reproductions were available as templates, including detailed shots of the adoring angels. ${ }^{60}$ The connection between the late nineteenth-century photograph (Fig. 4) and the example in Fig. 3, from the Fisher Antiphonary, is not limited to the possibility that this sort of photograph might have served as a model for Fig. 3 and leaf no. 1 in the Appendix. Both the copying of illuminations and the colouring of photographs were considered possible activities for 'wet mornings'. ${ }^{61}$ Fig. 4 is such a hand-coloured photograph.

To understand the rationale that lies behind these modern illuminations it is necessary to trace the nineteenth-century interest in manuscript production and, specifically, illumination practices. The manuals that instruct students in the art of illumination are very informative regarding how a manuscript should be designed. One of the most successful of these, A Manual of Illumination on Paper and Vellum, ${ }^{62}$ was in its eighteenth edition by 1870 . In this volume, under the headings 'conception', 'invention', and 'completion', the stated rules for manuscript design can be related to the examples from the Fisher Antiphonary.

'Conception' addresses selection of the individual elements to be copied, such as border decoration, initials, and text. The purpose is not to create a facsimile but, rather, to rearrange and borrow, and the reader is advised to: 'First dispossess yourself of the idea that good "design" must be entirely original' ${ }^{63}$ It is with 'invention' that deviations from the template are encouraged:

56 'Il gruppo più bello è di angioli genuflessi con le mani giunte, perchè arrivati al presepio, dove è il Redentore, adorano e pregano' (Benvenuti 1901, 19-20).

57 Ledger 1978, 181.

58 Ledger 1978, 181, 183, 278 and 295.

59 Ledger 1978, 123 and 131.

60 See, for example, the sales catalogues from two different shops: Alinari 1873, 138 and Brogi 1878, 75 .

61 Watson 2007, 94.

62 Bradley et al. 1870.

63 Bradley et al. 1870, 95-96. 
For our second point - invention - the beginner, with a view to gradual improvement, should at first copy a part of an illuminated page, the mere border for instance, and the miniature capital or great initials (according to word required to begin a certain passage) from another page of the same MSS., so as to ensure same style, and unite it to [the] border, [...]. In your next attempt you might alter the details a little, such as the setting of leaves. ${ }^{64}$

However, not only illuminated manuscripts were put forward as models; in principle, everything could be used according to one's taste. The reader is advised that ' $[. .$.$] when you see a good thing in drawing and colour that strikes you$ as adapted for illumination, to take note thereof, and try something like it' ${ }^{65}$ The aspiring illuminator should ideally create a personal model book and annotate the copies with dates of their originals, ${ }^{66}$ because mixing elements from different centuries was not recommended. ${ }^{67}$ Finally, colours and additional decorative elements complete the newly created manuscript page. ${ }^{68}$

With such ideas for designing manuscripts, the Fisher Antiphonary - and related objects ${ }^{-69}$ can be better located within the nineteenth century, at least as far as its new decoration system and related decisions are concerned.

\section{Music as image}

In A Manual of Illumination on Paper and Vellum the reader is informed that, as part of the 'conception', the textual content plays an essential role and the text should coordinate with the illumination. ${ }^{70}$ The primary deviation of the Fisher Antiphonary, and leaves nos 1-4 from the manual's design rules lies in the disjunction between motifs in the modern miniatures and initials, and the liturgical contents of the Late Medieval or Renaissance choir book pages that were used to paint on (e.g. Figs 1 and 3)..$^{71}$

64 Bradley et al. 1870, 96.

65 Bradley et al. 1870, 98. Architecture and glass paintings are explicitly mentioned.

66 Bradley et al. 1870, 73.

67 Bradley et al. 1870, 36.

68 Bradley et al. 1870, 98.

69 Discussion of the Spanish Forger's manuscripts may profit from including the ideas of conception, invention, and completion.

70 Bradley et al. 1870, 39.

71 The use of parchment to paint on was recommended in the manuals, because it is obvious that good copies of ancient illuminated manuscripts can be made on this material only, for there is a charm about the colour and texture of well-prepared calf-skin, which no paper can be 
There is no question that the musical notation of the chants no longer served their function of celebrating Mass or Office. However, in leaving most of the musical notation intact and visible it could serve as part of the 'conception', which was not intended to be a collage of single elements (as in Fig. 2), but rather an imitation of the layout of choir books that travellers could marvel at in Florence and Siena. This function of musical notation becomes particularly clear in cases in which new parchment was used, and invented notation was entered as part of the design (Appendix, no. 8).

Musical notation as an image can also be found in the painting templates of Vittorio Vultens's La Miniatura sulla Pergamena. Fig. 5 shows one of his painting templates. An initial 'P' contains a scene showing Saint Cecilia, the patron saint of music, standing in front of a huge choir book with two angels behind her. While Cecilia is usually represented with an organ or other instruments, here it is the choir book that stands out. To the best of my knowledge, this is a representation of Cecilia originating in the nineteenth century and especially popular among nineteenth-century painters, who not only collected illuminated choir books and single leaves, but also integrated them into their paintings. ${ }^{72}$ In fact, this depiction comes not from Vulten himself, but is a copy of a painting by Giulio Aristide Sartorio (1860-1932), which was reproduced as an engraving in the magazines L'Illustrazione Italiana and L'illustrazione popolare. ${ }^{73}$ Several differences between these two can be identified. While Sartorio's choir book, for example, only shows large initials, Vulten adds invented notation. Although Vulten uses a contemporary model, he describes the style of his initials as 'stile antico' - which he defines as the period between the ninth and sixteenth centuries. $^{74}$

Taken as a whole, in the late nineteenth century we can see a shift from specific interest in single initials or miniatures to general interest in the complete parchment leaf or codex. Additionally, by the beginning of the twentieth century, a large number of printed books were available that imitated the look of illuminated manuscripts, as, for example, Jacopo Olivotto's S. Francesco

made to possess'. On the other hand, new parchment was considered costly (Tymms and Wyatt 1860, 50, and Bradley et al. 1870, 29).

72 For example, John William Waterhouse, Saint Cecilia (1895), <https://commons.wikimedia. org/wiki/File:Waterhouse,_John_William_-_Saint_Cecilia_-_1895.jpg $>$.

73 L'Illustrazione Italiana, 5 April 1891, L'illustrazione popolare. Giornale per le famiglie, 20 December 1891, 803, 804, and 812. Later Sartorio created a similar work including an enormous notated Missal, published in L'Illustrazione Italiana, 6 January 1895, p. 1 and 15.

74 Vulten 1905, 18-20. 
d'Assisi nel Poema di Dante e negli Affreschi di Giotto (Florence, 1905), which was reviewed with a great deal of interest:

The Canto XI of Dante's Paradiso is printed with characters, with friezes and initials, which perfectly imitate the most beautiful manuscripts of that century, and the chromolithographs reproducing Giotto's most beautiful paintings lead us to the originals [...]. ${ }^{75}$

In this spirit, the Fisher Antiphonary and Appendix nos 1-4 can be understood as souvenirs of a sort. The 'conception' of each newly illuminated leaf imitates the old choir book openings in the display cases and each of the individual elements copied refers to a different original. In the case of the folios, which include motifs from Gozzoli and Lippi, reference is made to especially well-known Florentine tourist attractions. In the two folios with copies of Gozzoli's adoring angels (Fig. 3 and Appendix, no. 1), one might even interpret the notation as a representation of the angelic singing, as the choirs of angels in the two Palazzo Medici-Riccardi altar panels sing the Gloria. This point is emphasised in the travel guides:

[...] with the heavenly expression of the angels who, hand in hand, advance singing the praises of the Virgin. The illusion is so complete that it seems as if, looking intently for a few minutes, one must hear their voices' ${ }^{76}$

This study set out to gain a better understanding of manuscript illumination in Nineteenth-Century Italy, which so far has received only little attention compared to studies on Great Britain, France, or Belgium. One task was to explore the different agents in the context of contemporary manuscript admiration, which was mostly centred on strong visual characteristics and the material object as such, rather than on the actual content. In some cases the content was of interest only because of its visual quality, as for example the musical notation in the Fisher Antiphonary. It is beyond the scope of this article to examine the relationship between the illuminations made in the nineteenth century or early twentieth century and their models in detail, however, in a future study, I will analyse a music manuscript which was copied from frequently in NineteenthCentury Florence.

75 'Il Canto XI del Paradiso di Dante è stampato con caratteri, con fregi ed iniziali, che imitano perfettamente i più bei manoscritti di quel secolo, e le cromo-litografie riproducenti i più bei quadri di Giotto ci portano col pensiero agli originali che in quell'epoca furono fissati nelle artistiche pareti di S. Francesco in Assisi e di S. Croce in Firenze.' Fiumi Roncalli 1906, 36.

76 Grifi 1896, 145. See also Benevenuti 1901, 19-23. 


\section{References}

Alinari, Fratelli [brothers] (eds) (1873), Catalogo generale delle riproduzioni fotografiche, Florence: Tipografia di G. Barbèra.

Ascoli, Francesco (2007), 'L'enluminure italienne au XIXe siècle. Un renouveau méconnu', in Coomans and de Maeyer (eds) 2007, 197-205.

Benvenuti, G. B. (1901), Gli affreschi di Benozzo Gozzoli nella Cappella del Palazzo Riccardi, Florence: Galletti \& Cocci.

Biagi, Guido (1890), 'Una pergamena', L'Illustrazione Italiana, 43: 269.

Bosch, Sebastian and Andreas Janke (2021), 'Manuscript Illumination in 19th-century Italy. Material Analysis of Two Partial Copies from the Squarcialupi Codex', Open Information Science, 5: 63-88 <https://doi.org/10.1515/opis-2021-0006>.

Bradley, John William, T. G. Goodwin and J. J. Laing (1870), A Manual of Illumination on Paper and Vellum, 18th edn, London: Winsor and Newton.

Brogi, Giacomo (ed.) (1878), Catalogue général des photographies, Florence: Établissement Civelli.

Chapron, Emmanuelle (2004), 'Voyageurs et bibliothèques dans l'Italie du XVIIle siècle: des “mirabilia” au débat sur l'utilité publique', Bibliothèque de l'École des chartes, 162/2: 455-482.

Coomans Thomas and Jan de Maeyer (eds) (2007), The Revival of Medieval Illumination. Nineteenth-century Belgium Manuscripts and Illuminations from a European Perspective (KADOC artes, 8), Leuven: Leuven Univ. Press.

Doll, Martin (2012), Fälschung und Fake. Zur diskurskritischen Dimension des Täuschens (Kaleidogramme, 78), Berlin: Kulturverlag Kadmos.

Eco, Umberto (1990), The Limits of Interpretation, Bloomington, IN: Indiana University Press.

Fiumi Roncalli, Antonio (1906), 'Relazione annuale', Bolletino della società internazionale degli studi francescani in Assisi, August 1906: 25-39.

Galopp, Annabel Teh (2017), ‘Fake or Fancies? Some “Problematic” Islamic Manuscripts from South East Asia', manuscript cultures, 10: 101-128.

Grifi, Elvira (1896), Saunterings in Florence: A New Artistic and Practical Hand-Book for English and American Tourists, Florence: Bemporad \& Figlio.

Guernelli, Daniele (2011), 'Ritagli di Memoria. Cuttings, Collages e Miniatura in Italia tra XIX e XX secolo', Opus Incertum, 6-7: 30-41.

Hindman, Sandra and Nina Rowe (eds) (2001), Manuscript illumination in the modern age: recovery and reconstruction [this catalogue was published in conjunction with the Exhibition, Manuscript Illumination in the Modern Age, Mary and Leigh Block Museum of Art, 11 January - 4 March 2001], Evanston, IL: Mary and Leigh Block Museum of Art, Northwestern University.

Holy Hoaxes. A Beautiful Deception. Celebrating William Voelkle's Collecting, Catalogue to the Exhibition, 17 January - 2 February 2019, New York, <https://www.lesenluminures.com/ usr/library/documents/main/holy-hoaxes-catalogue.pdf $>$.

Horner, Susan and Johanna (1884), Walks in Florence and its Environs, 2 vols, London: Smith, Elder \& Co.

Keazor, Henry (2018), 'Six Degrees of Separation. The Foax as More', in Daniel Becker, Annalisa Fischer, Yola Schmitz (eds), Faking, Forging, Counterfeiting. Discredited Practises at the Margins of Mimesis, Bielefeld: Transcript, 11-40. 
Labriola, Ada (2016), 'Miniature rinascimentali riprodotte nel XIX secolo. Gaetano Milanesi, Carlo Pini e Giovanni Rosini: dai calchi grafici alle stampe di traduzione', Rivista di Storia della Miniatura, 20: 155-169.

Labriola, Ada (2020), I manoscritti miniate del museo di San Marco a Firenze. Corali francescani (1440-1530), Florence: Edizioni Polistampa.

Ledger, Tanya (1978), A Study of the Arundel Society, 1837-1897, PhD thesis, St Hilda's College Oxford.

Melani, Alfredo (1896), Manuale dell'ornatista (Manuali Hoepli), Milan: Hoepli.

Michel, Cécile and Michael Friedrich (eds) (2020), Fakes and Forgeries of Written Artefacts from Ancient Mesopotamia to Modern China (Studies in Manuscript Cultures, 20), Berlin: De Gruyter.

Michel, Cécile and Michael Friedrich (2020), 'Fakes and Forgeries of Written Artefacts: An Introduction', in Cécile Michel and Michael Friedrich (eds) 2020, 1-22.

Milanesi, Gaetano (1850), Storia della Miniatura Italiana con Documenti Inediti, Florence: s.n. Murray, John (1867), Murray's Handbook of Florence and its Environs, London: John Murray. Orcutt, William Dana (1926), In Quest of the Perfect Book. Reminiscences and Reflections of a Bookman, Boston, MA: Little Brown \& Co.

Piazza, Manuel (2019), A Study and CANTUS Index of MSS 09700: 'The Fisher Antiphoner', MA thesis, University of Toronto.

Rabin, Ira and Oliver Hahn (2020), 'Detection of Fakes: The Merits and Limits of Non-Invasive Materials Analysis', in Cécile Michel and Michael Friedrich (eds) 2020, 281-290.

Rigby, Elizabeth (1895), Journals and correspondence of Lady Eastlake, 2 vols., ed. Charles E. Smith, London: Murray.

Römer, Stefan (2006), 'Zwischen Kunstwissenschaft und Populismus: Die Rede vom Original und seiner Fälschung', in Anne-Kathrin Reulecke (ed), Fälschungen. Zu Autorschaft und Beweis in Wissenschaften und Künsten, Frankfurt am Main: Suhrkamp, 347-363.

Rondoni, Ferdinando (1872), Guida del R. Museo Fiorentino di S. Marco con aggiunta di brevi notizie sulla chiesa annessa, Florence: Tipografia Cenniniana.

The Spanish Forger: Master of Deception, Exhibition, 10 December 1987 - 28 February 1988, Patrick and Beatrice Haggerty Museum, Milwaukee, WI.: Marquette University, 1987.

Voelkle, William M. (1978), The Spanish Forger [published in conjunction with an exhibition Pierpont Morgan Library, New York, 19 May - 29 July 1978], New York: Pierpont Morgan Library.

Voelkle, William M. (2007): ‘The Spanish Forger. Master of Manuscript Chicanery’, in Coomans and de Maeyer (eds) 2007, 207-227.

Vulten, Vittorio (1905), La miniatura sulla pergamena. Corso teorico pratico, Milan: Cartotechnica Italiana Binetti Fraschini e C.

Watson, Rowan (2007), 'Publishing for the Leisure Industry. Illuminating Manuals and the Reception of a Medieval Art in Victorian Britain', in Coomans and de Maeyer (eds) 2007, 79-108.

Wieck, Roger S. (1996), 'Folia Fugitiva: The Pursuit of the Illuminated Manuscript Leaf', The Journal of the Walters Art Gallery, 54: 233-254. 


\section{Appendix: Modern illuminations on parchment leaves}

No. 1

New York, Doyle, Auction, 3 May 2006, Books and Print, Sale 06BP01, Lot $3004^{77}$ Dimensions: c. $381 \mathrm{~mm} \times 260 \mathrm{~mm}$.

Description: The framed fragment from a Late Medieval choir book was sold for $\$ 2,400$; the current owner is unknown. The modern miniature includes three adoring angels copied on top of musical notation and text. The template was the left panel of Benozzo Gozzoli's fresco in the Chapel of the Magi in the Palazzo Medici-Riccardi in Florence, or some other media that reproduced the fresco; see, for example, the hand-coloured photograph from the late nineteenth century at <http://doi.org/10.25592/uhhfdm.1881>.

The decorations around the miniature stem from different Florentine illuminated manuscripts coeval with the creation of Gozzoli's fresco. The artefact was most likely illuminated in the same environment as the Fisher Antiphonary.

\section{No. 2}

New York, Private Collection, William Voelkle (acquired from Thomas Carson, 1987).

Dimensions: $425 \mathrm{~mm} \times 315 \mathrm{~mm}$.

Description: A leaf from an Italian Antiphonary. A modern historiated initial ' $\mathrm{B}$ ' was entered in the upper left corner, covering the musical notation and text. Voelkle demonstrates that the historiated initial does not relate liturgically to the leaf's contents.

Bibliography: The Spanish Forger, 1987, 32, no. 24; Holy Hoaxes 2019, 41.

\section{No. 3}

San Francisco, Fine Arts Museums, Achenbach Foundation for Graphic Arts, $25644^{78}$ (Gift of Sarah M. Spooner, acquired 3 March 1904).

Dimensions: $387 \mathrm{~mm} \times 274 \mathrm{~mm}$.

Description: A leaf from an Italian choir book. On its recto the parchment leaf contains the foliation number 'vi'. More than half of the recto side is taken up by

$77<$ https://doyle.com/auctions/06bp01-books-and-prints/catalogue/3004-illuminatedmanuscript $>$.

$78<$ https://art.famsf.org/anonymous/page-choral-miniature-resurrection-christ-25644>. 
a large historiated initial ' $R$ ' which obscures the chant. The leaf was probably illuminated in the same environment as the Fisher Antiphonary.

\section{No. 4}

New York, Private Collection, William Voelkle (from the collection of Cornelius J. Hauck).

Dimensions: $245 \mathrm{~mm} \times 310 \mathrm{~mm}$.

Description: The incomplete parchment leaf was acquired at Sotheby's New York auction 'The History of the Book: The Cornelius J. Hauck Collection' (27-28 June 2006) for $\$ 720$. It is a palimpsest; the lower script contains a Jewish marriage contract from the eighteenth century, whereas the overwriting shows part of a Gradual with border decorations and an initial $\mathrm{N}$ that were copied from the same template as no. 8. The scene within the initial, however, does not fit liturgically as Voelkle points out.

Bibliography: Holy Hoaxes 2019, $44 .^{79}$

\section{No. 5}

San Francisco, Fine Arts Museums, Achenbach Foundation for Graphic Arts, $25650^{80}$ (Gift of Sarah M. Spooner, acquired 3 March 1904).

Dimensions: $264 \mathrm{~mm} \times 180 \mathrm{~mm}$.

Description: This parchment leaf contains a Florentine credit contract from 2 October 1800, main text printed with handwritten inserts. On the verso a fullpage miniature was added in the nineteenth century. The image was copied from Fra Filippo Lippi's Adoration of the Child, c. 1435, now in the Uffizi Galleries, Florence, and it resembles the style of the historiated initial in fol. $69^{\mathrm{r}}$ of the Fisher Antiphonary (Fig. 1).

\section{No. 6}

New York, Pierpont Morgan Library, Manuscript M.260e $e^{81}$

Dimensions: not indicated.

Description: Facsimile of Florence, Museo di San Marco, gradual B, MS 516, fol. $3^{\mathrm{r}}$. The lower left corner contains the name of the illuminator, Jacopo Olivotto.

79 See also <https://www.christies.com/lot/lot-4747496/?hdnSaleID=20680\&LN=140\&intsaleid= 20680>.

$80<$ https://art.famsf.org/anonymous/parchment-miniature-nativity-25650>.

$81<$ corsair.themorgan.org/vwebv/holdingsInfo?bibId=278210>. 


\section{No. 7}

Milwaukee, Haggerty Museum of Art, $79.21^{82}$ (Gift of Eva K. Ford, Genoa, Nebraska) Dimensions: $533 \mathrm{~mm} \times 432 \mathrm{~mm}$.

Description: Leaf from a choir book with a modern historiated initial M. The scene within the initial was copied in 1908 - and signed - by E. Giandotti from Fra Angelico's fresco The Annunciation in the monastery of San Marco.

Bibliography: Voelkle, The Spanish Forger 1987, 33 (No. 37).

\section{No. 8}

Vienna (Deutsch Auctioneers), Lot 53, two framed folios ${ }^{83}$

Dimensions: $420 \mathrm{~mm} \times 300 \mathrm{~mm}$.

Description: The two framed leaves were offered at auction on 25 September 2018 with an estimated price range of $€ 1600-2800$. From the online images it can be seen that the two leaves were created in the nineteenth or early twentieth century on new parchment. The first leaf is a facsimile of fol. $7^{\mathrm{v}}$ in manuscript Florence, Biblioteca Medicea Laurenziana, Med. Pal. 87. The second leaf is an imitation of decorations in the same codex - the initial ' $N$ ' and most of the marginal decoration are taken from the same exemplar as no. 4. The musical notation is invented.

$82<\mathrm{http}: / /$ museum.marquette.edu/eMuseumPlus?service=ExternalInterface\&module= collection\&objectId=3591\&viewType=detailView $>$.

83 I thank Margaret Bent for bringing this auction to my attention. Lot 53 was advertised under the following link - accessed 18 Sept. 2018 - the images and descriptions are no longer available online at the auctioneer's website (<deuart.at/index.php/auction/upcoming-auction/detailview/116-lot53-detail>). But see: <https://www.invaluable.com/auction-lot/pair-of-illuminatedincunables-53-c-7864ec2a06>. 


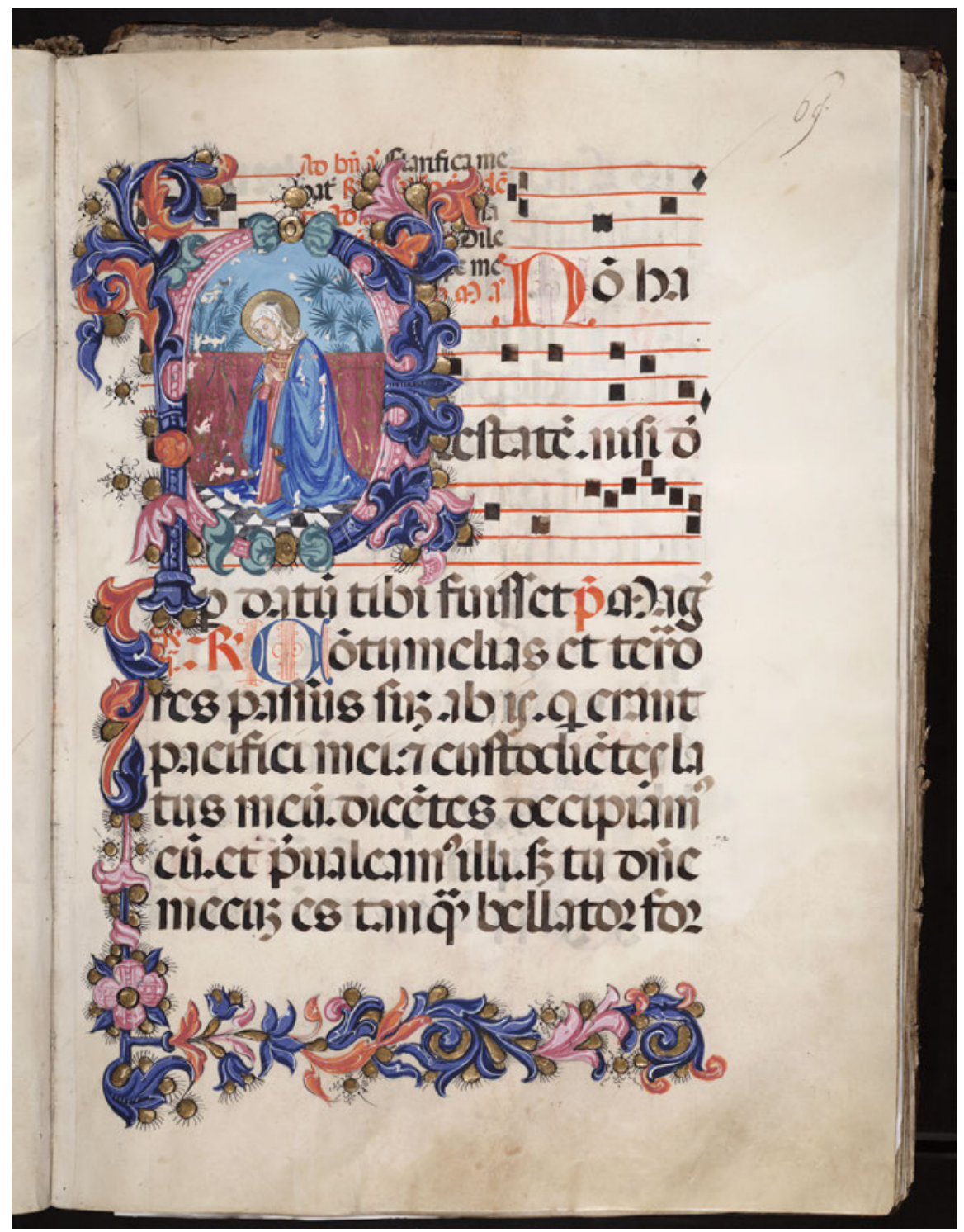

Fig. 1: Toronto, Thomas Fisher Rare Book Library, MSS 09700, fol. 69' ${ }^{r}$. Manuscript digitised: 〈https://collections.library.utoronto.ca/view/fisher2:F6521〉. () Thomas Fisher Rare Book Library, Toronto. 


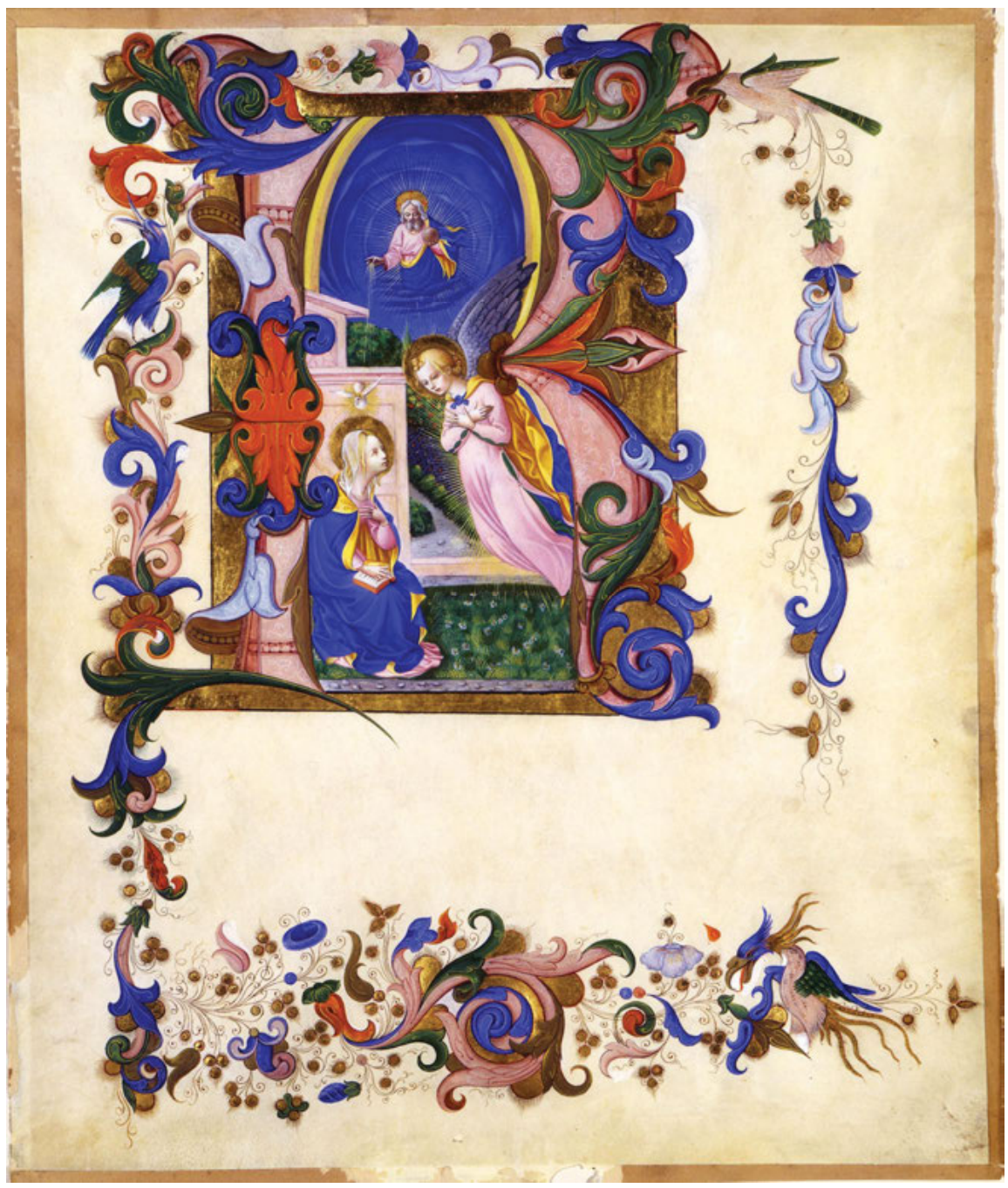

Fig. 2: London, Victoria and Albert Museum, Museum number E.120-1996, recto. <https://collections.vam.ac.uk/item/094146/manuscript-strozzi-zanobi〉. (C) Victoria and Albert Museum, London. 


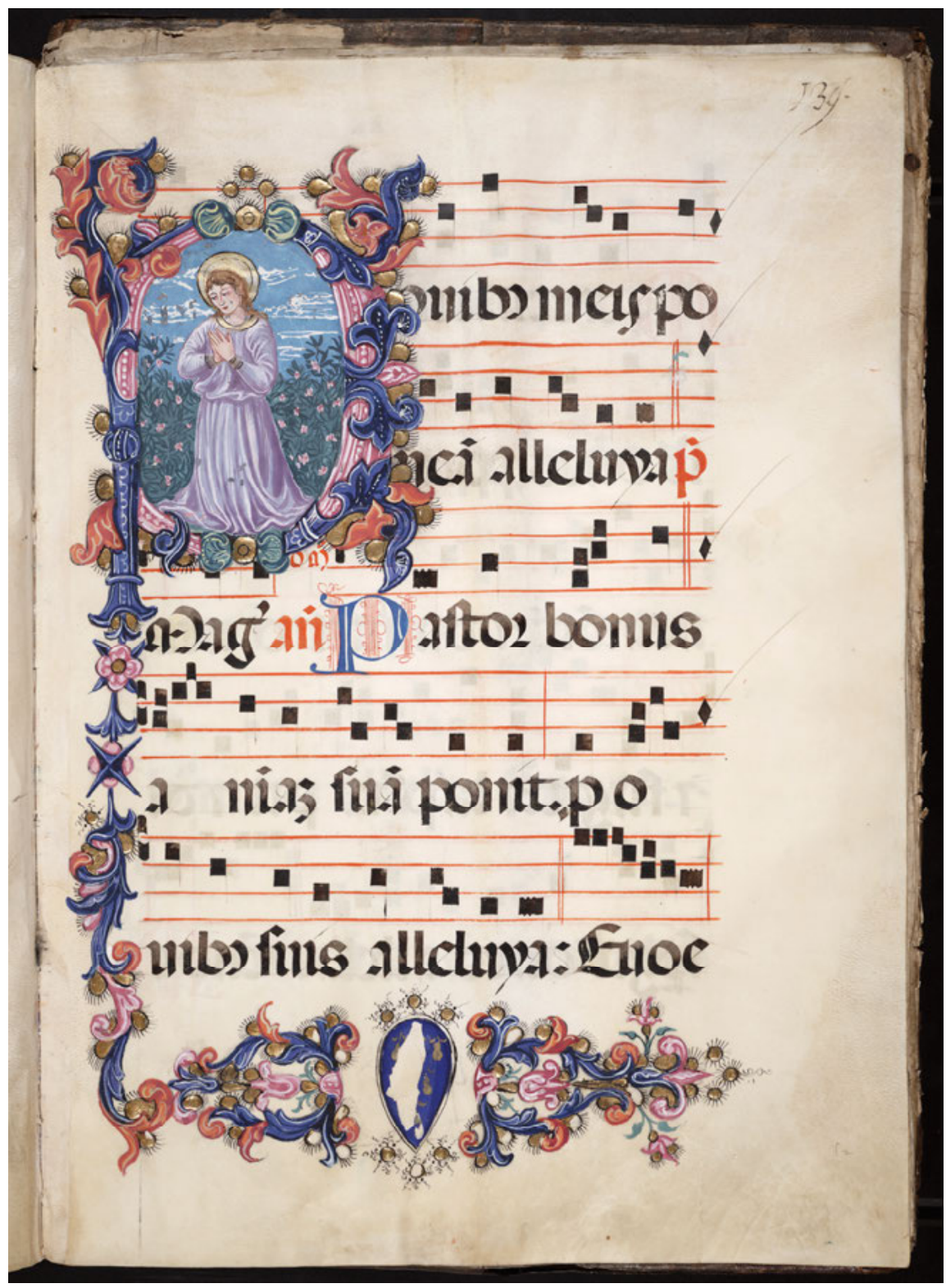

Fig. 3: Toronto, Thomas Fisher Rare Book Library, MSS 09700, fol. 139'. (c) Thomas Fisher Rare Book Library, Toronto. 


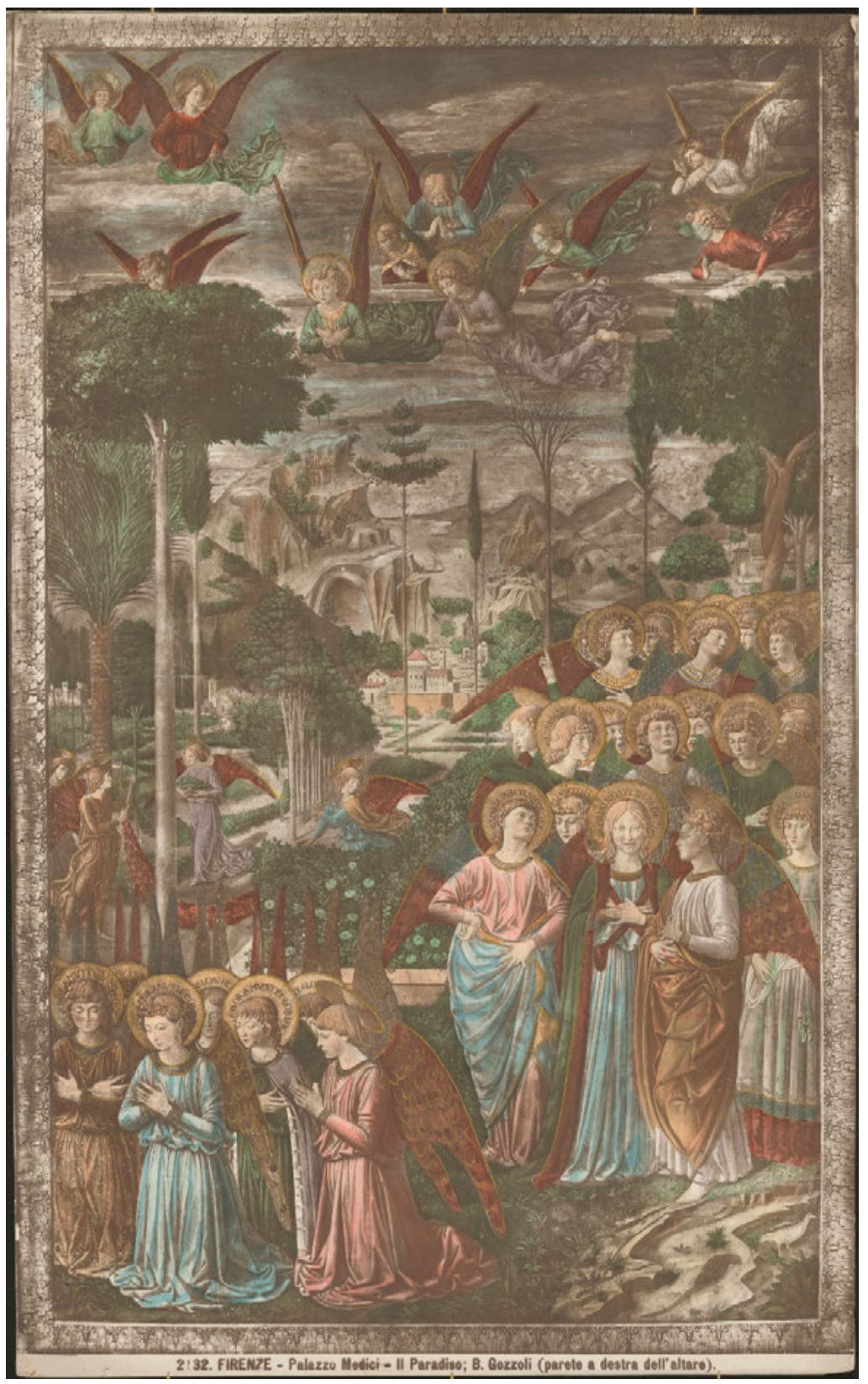

Fig. 4: Photograph of Benozzo Gozzoli's fresco on the wall at the right of the altar in the chapel of the Palazzo Medici-Riccardi, late nineteenth century, hand-coloured (private collection). High-resolution colour images are available at <doi.org/10.25592/uhhfdm.1881〉. 
TAY. 8

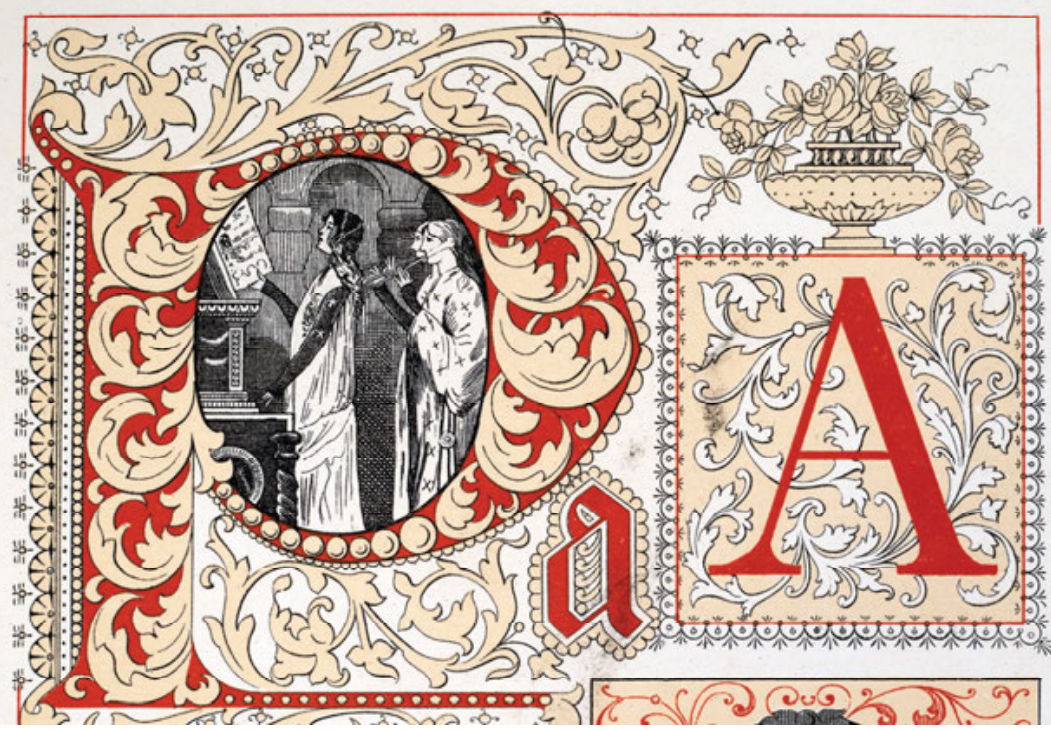

Fig. 5: Detail from Table 8 in Vulten 1905. 